\title{
Obestatin Enhances In Vitro Generation of Pancreatic Islets through Regulation of Developmental Pathways
}

\author{
lessandra Baragli, Cristina Grande, lacopo Gesmundo, Fabio Settanni, Marina Taliano, Davide Gallo, \\ Eleonora Gargantini, Ezio Ghigo, Riccarda Granata*
}

Division of Endocrinology, Diabetology and Metabolism, Department of Medical Sciences, University of Torino, Torino, Italy

\begin{abstract}
Availability of large amounts of in vitro generated $\beta$-cells may support replacement therapy in diabetes. However, methods to obtain $\beta$-cells from stem/progenitor cells are limited by inefficient endocrine differentiation. We have recently shown that the ghrelin gene product obestatin displays beneficial effects on pancreatic $\beta$-cell survival and function. Obestatin prevents $\beta$-cell apoptosis, preserves $\beta$-cell mass and stimulates insulin secretion in vitro and in vivo, in both normal and diabetic conditions. In the present study, we investigated whether obestatin may promote in vitro $\beta$-cell generation from mouse pancreatic islet-derived precursor cells. Treatment of cultured islets of Langerhans with obestatin (i) enriched cells expressing the mesenchymal/neuronal marker nestin, which is associated with pancreatic precursors; (ii) increased cell survival and reduced apoptosis during precursor selection; (iii) promoted the generation of islet-like cell clusters (ICCs) with increased insulin gene expression and C-peptide secretion. Furthermore, obestatin modulated the expression of fibroblast growth factor receptors (FGFRs), Notch receptors and neurogenin 3 (Ngn3) during islet-derived precursor cell selection and endocrine differentiation. These results indicate that obestatin improves the generation of functional $\beta$-cells/ICCs in vitro, suggesting implications for cell-based replacement therapy in diabetes. Moreover, obestatin may play a role in regulating pathways involved in pancreas development and regeneration.
\end{abstract}

Citation: Baragli I, Grande C, Gesmundo I, Settanni F, Taliano M, et al. (2013) Obestatin Enhances In Vitro Generation of Pancreatic Islets through Regulation of Developmental Pathways. PLoS ONE 8(5): e64374. doi:10.1371/journal.pone.0064374

Editor: Miguel López, University of Santiago de Compostela School of Medicine - CIMUS, Spain

Received February 8, 2013; Accepted April 11, 2013; Published May 31, 2013

Copyright: (c) 2013 Baragli et al. This is an open-access article distributed under the terms of the Creative Commons Attribution License, which permits unrestricted use, distribution, and reproduction in any medium, provided the original author and source are credited.

Funding: This work was supported by the following grants: Regione Piemonte 2008, Brain Drain University of Turin 2008 , PRIN 2008 (to R.G.); Compagnia di San Paolo 2008 (to E.G.) and 2011 (to R.G.); Studio delle Malattie Endocrino Metaboliche (SMEM) Foundation (Turin, Italy); NIT (Neuroscience Institute of Turin), and GISNe (Italian Group of Neuroendocrine Sciences). There are no conflicts of interest. The funders had no role in study design, data collection and analysis, decision to publish, or preparation of the manuscript.

Competing Interests: The authors have declared that no competing interests exist

*E-mail: riccarda.granata@unito.it

\section{Introduction}

In vitro generation of functional $\beta$-cells may help to overcome the shortage of pancreatic islets for replacement therapy in diabetes [1]. To date, insulin-expressing cells have been derived from stem cells (SCs), induced pluripotent stem cells (iPSCs) and precursors obtained from different tissues [1-5]. Functional $\beta$-cells in vitro may be obtained by regulating the expression of genes involved in pancreatic development. This has been attempted through genetic reprogramming and/or growth factor supplementation [1-6]. However, despite some success, the use of SCs and genetically reprogrammed cells has raised both ethical and safety issues, whereas growth factor supplementation alone resulted in the generation of $\beta$-cells with inefficient insulin synthesis and secretion [1].

In vivo $\beta$-cell regeneration in adult human and mouse pancreas involving in situ precursor cells [7-10] suggested that their higher degree of commitment and location would require less manipulation to differentiate into $\beta$-cells in in vitro settings [1]. Indeed, nestin $^{+} /$vimentin $^{+}$mesenchymal-like cells (MLCs) have been isolated and enriched from both rodent and human islets [1115]. These are multipotent stromal cells displaying epigenetic marks on the insulin gene, indicating priming for $\beta$-cells $[11,13-$ 16]. Once expanded, supplementation with specific growth factors or changes in cell culture condition may induce MLC differen- tiation into hormone expressing islet-like cell clusters (ICCs) containing putative $\beta$-cells $[11,13-15,17]$. However, ICGs inefficiently release insulin/C-peptide in response to glucose and display poor insulin gene expression $[11,12,14,15]$. This limitation is only in part overcome with ICG implantation in mice models of diabetes [12]. Thus, although in vitro generation of transplantable ICGs from MLCs appears a promising approach to cell replacement therapy, it is still technically challenging.

Obestatin, was discovered as a new ghrelin gene-derived peptide and proposed to bind to the GPR39 orphan receptor and to exert effects opposed to those of acylated ghrelin on food intake [18]. However, both assumptions have been questioned and obestatin physiological role is still quite unknown [19,20]. Our recent findings suggested that the glucagon-like peptide 1 receptor (GLP-1R) may be involved in at least part of obestatin activities, implying therapeutic potential in metabolic dysfunctions and diabetes [21]. Indeed, obestatin stimulates glucose-induced insulin secretion in vitro in $\beta$-cell lines and human pancreatic islets [21], and in vivo in mice [22] and in perfused rat pancreas [23]. Moreover, like ghrelin [24], obestatin inhibits apoptosis of pancreatic $\beta$-cells and human islets, and up-regulates genes essential for $\beta$-cell survival and endocrine differentiation [21]. In vivo obestatin prevents diabetes in streptozotocin (STZ)-treated rats [25] and reduces insulin resistance in mice fed a high fat diet [22]. Although being mainly produced by the stomach [18], obestatin 
expression in fetal, neonatal and adult pancreas may imply a role in pancreas development and homeostasis $[20,26]$. Based on the foregoing, we hypothesized that obestatin would influence pancreatic precursor differentiation into $\beta$-cells. Therefore, we studied obestatin effects on in vitro differentiation of mouse pancreatic islet-derived MLGs into functional $\beta$-cells/ICGs.

\section{Materials and Methods}

Mouse amidated obestatin (1-23) was from Phoenix Pharmaceuticals (Karlsruhe, Germany). Tetramethyl-6-carboxyrhodamine (TAMRA)-obestatin was from Inbios, Naples, Italy. Cell culture reagents were from GIBCO (Life Technologies, Milan, Italy). Rabbit cytokeratin 19, GLP-1R, ghrelin and somatostatin antibodies were from Santa Cruz Biotechnology (DBA, Milan, Italy). Rabbit GPR39, Oct3/4, PDX1, $\beta$-actin antibodies and guinea pig serum insulin antibodies were from Abcam (Cambridge, UK). Alexa Fluor-labeled antibodies were from Molecular Probes (Invitrogen, Milan, Italy). Mouse fibroblast growth factor (FGF2) monoclonal antibody and FGF2-neutralizing antibodies were from Millipore (Milan, Italy). Ngn3 antibody was from Chemicon (Milan, Italy). Primers for RT-PCR were synthesized by Tema Ricerche (Bologna, Italy), All other reagents were from Sigma Aldrich unless specified in the text.

\section{Animals}

Male C57BL6/J mice (6-7 months-old) were used for pancreatic islet isolation. Mouse procedures conformed to Guide for Care and Use of Laboratory Animals of the U.S. National Institute of Health and all procedures were approved by the animal care and use committee of the University of Turin. All mice were doublehoused on a 12-h light, 12-h dark cycle (6 am lights on- 6 pm lights off) at $22^{\circ} \mathrm{C}$ and provided standard chow and water ad libitum. Mice were anesthetized with tribromoethylalcohol (Avertin; $375 \mathrm{mg} / \mathrm{kg}$ i.p.) and euthanized by cervical dislocation.

\section{Islet Isolation and Cell Cultures}

Pancreases were excised, minced (stage 1) and digested as described [27]. Digestion was quenched by addition of FBS, tissues collected through centrifugation (stage 2), resuspended in RPMI1640 with $10 \%$ FBS and $2 \mathrm{mM}$ glutamine, and plated in $100 \mathrm{~mm}$ dishes. Within 3-4 days the exocrine and ductal tissues attached to the dish or died (stage 3). At day 4, 85-95\% of floating cell aggregates were positive to dithizone and $99 \%$ negative to the ductal marker cytokeratin 19 (Cyto19). Islet yield, over six extractions, was $1142.5 \pm 190$ islets/mouse. Enriched islets were collected, plated in 6 or 24 multi-well plates coated with $4 \mu \mathrm{g} / \mathrm{ml}$ fibronectin, $1 \mu \mathrm{g} / \mathrm{ml}$ concanavalin $\mathrm{A}, 0.001 \%$ poly-L-ornithin (day 1, stage 4) and maintained in DMEM low glucose $(5.5 \mathrm{mmol} /$ L) containing $2 \mathrm{mmol} / \mathrm{L}$ glutamine and $10 \%$ FBS. $\approx 45-55$ islets were plated in each well of a 6 -well plate and 20 in a 24 -well plate. Half of the dishes were treated with obestatin $(100 \mathrm{nmol} / \mathrm{L})$ every two days. The majority of islets attached to the dish within 3-6 days (stage 4) and no difference in the number of adherent islets was observed upon obestatin treatment. During stage 4 mesenchymal-like cells (MLCs) emerging from the islets were allowed to expand. After 4 days fresh medium was added and at day 6 changed into serum free DMEM/F12 containing $26 \mathrm{mmol} / \mathrm{L}$ glucose, $2 \mathrm{mmol} / \mathrm{L}$ glutamine, $1400 \mathrm{U} / \mathrm{ml} \mathrm{LIF}, 20 \mathrm{ng} / \mathrm{ml} \mathrm{FGF}$, $20 \mathrm{nmol} / \mathrm{L}$ ITS (insulin, selenite, transferrin), $5 \mu \mathrm{g} / \mathrm{ml}$ fibronectin (day 1, stage 5). Cells were never subcultured and medium was replaced twice, with obestatin addition $(100 \mathrm{nmol} / \mathrm{L})$. From day 6 , with appearance of MLCs tridimensional clusters, fresh medium $(300 \mu \mathrm{l})$ was added every two days, with obestatin $(100 \mathrm{nmol} / \mathrm{L})$, up to day 15 of stage 5 . All experiments were performed the day after obestatin treatment.

\section{Islet Counting and Morphometric Analysis}

Islets were stained with dithizone for $20 \mathrm{~min}$ at $37^{\circ} \mathrm{C}$. Red cell clusters were counted as islets in 10 random fields. Microphotographs were taken at fixed time intervals $(10 \mathrm{X})$. Islet area was evaluated using Image J software (http://rsbweb.nih.gov/ij/) using a Leica DM200 microscope and a Leica DFC340 FX camera. Observations were repeated in 6 different isolations. Dithizone stained islets were not used for subsequent experiments.

\section{Insulin and C-peptide Secretion}

5 islets or ICGs were hand-picked under the microscope and incubated with different concentrations of D-glucose in KrebsRinger buffer to induce insulin/C-peptide secretion [21]. Lglucose, was used as molar control. Islets were collected, supernatants stored at $-20^{\circ} \mathrm{C}$ and tested for insulin and Cpeptide (mouse RIA and ELISA kit, respectively, Alpco Diagnostics, DiaSorin, Saluggia, Italy). Insulin was also tested in medium alone $(300 \mu \mathrm{l})$.

\section{Cell Migration}

Cell migration was assayed in Boyden's chambers. Cells were FGF2-starved for $12 \mathrm{~h}$, detached in PBS/0.5\% EDTA and resuspended in FGF2-deprived serum-free medium. 125,000 cells were seeded on $0.1 \%$ gelatine coated filters $(8-\mu \mathrm{m}$ pore size, NeuroProbe, DBA, Milan, Italy) and incubated at $37^{\circ} \mathrm{C}$ for $4 \mathrm{~h}$. The lower compartment contained serum-free medium either FGF2-deprived, with $100 \mathrm{ng} / \mathrm{ml} \mathrm{FGF2} \mathrm{or} 100 \mathrm{ng} / \mathrm{ml} \mathrm{FGF2} \mathrm{and}$ $2.5 \mu \mathrm{g} / \mathrm{ml} \mathrm{FGF2-neutralizing} \mathrm{antibody.} \mathrm{Trapped-cells} \mathrm{in} \mathrm{the} \mathrm{filter}$ were fixed in cold methanol and stained with $2 \%$ Giemsa, then counted in four different fields under a light microscope (Leika DMIL).

\section{RT-PCR and Real-time PCR}

RNA extraction and reverse transcription were performed as described [21]. For RT-PGR experiments, cDNA (9 $\mu \mathrm{l})$ was amplified (GeneAmp PCR System; Perkin Elmer, Milan, Italy) in $50 \mu \mathrm{l}\left(94^{\circ} \mathrm{C}\right.$ for $30 \mathrm{~s}$, for $64^{\circ} \mathrm{C}$ for $30 \mathrm{~s} ; 72^{\circ} \mathrm{C}$ for $30 \mathrm{~s}, 72^{\circ} \mathrm{C}$ for 7 min.) For semiquantitative analysis, we optimized cDNA amount and determined the optimal cycle number in the linear range of PCR amplification for each gene. PCR products were separated by $2 \%$ agarose gel electrophoresis and visualized by ethidium bromide staining. For real-time PCR, cDNA was treated with DNA-free DNase (LifeTech, Monza, Italy). Real-time PCR was performed with $50 \mathrm{ng}$ cDNA, $150 \mathrm{nmol} / \mathrm{L}$ of each primer and the IQ-SYBR-green mastermix (BioRad, Milan, Italy) using the ABI-Prism 7300 (Applied Biosystems). The expected fragment sizes, conditions and primers are reported in Table S1.

\section{Apoptosis}

Morphological changes in the nuclei of apoptotic cells were detected by Hoechst 33258, as described [21].

\section{Cell Survival and Dimension}

Cell survival was assessed as described [22]. Cells were detached from dishes with $0.05 \%$ trypsin/EDTA and stained with Trypan blue dye $(0.04 \% \mathrm{w} / \mathrm{v}$; Invitrogen). Cells were counted with a Countess automated cell counter (Invitrogen). Cell dimension was automatically calculated during this procedure and expressed in $\mu \mathrm{m}$. 
A

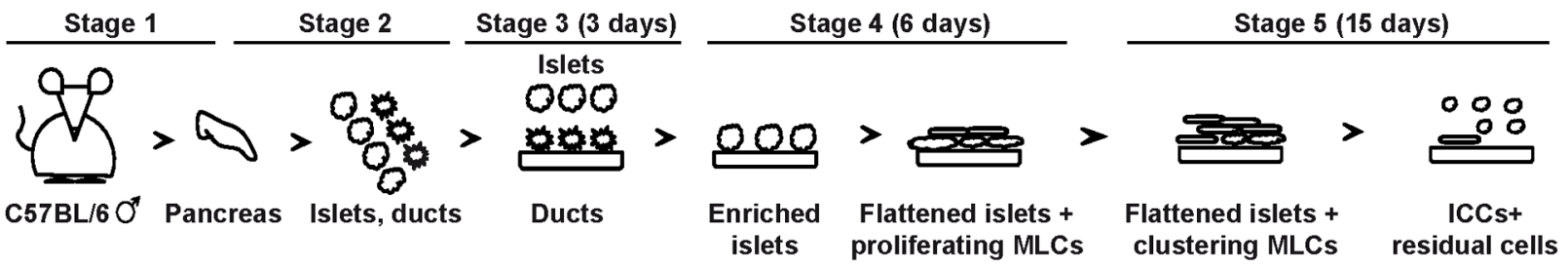

B

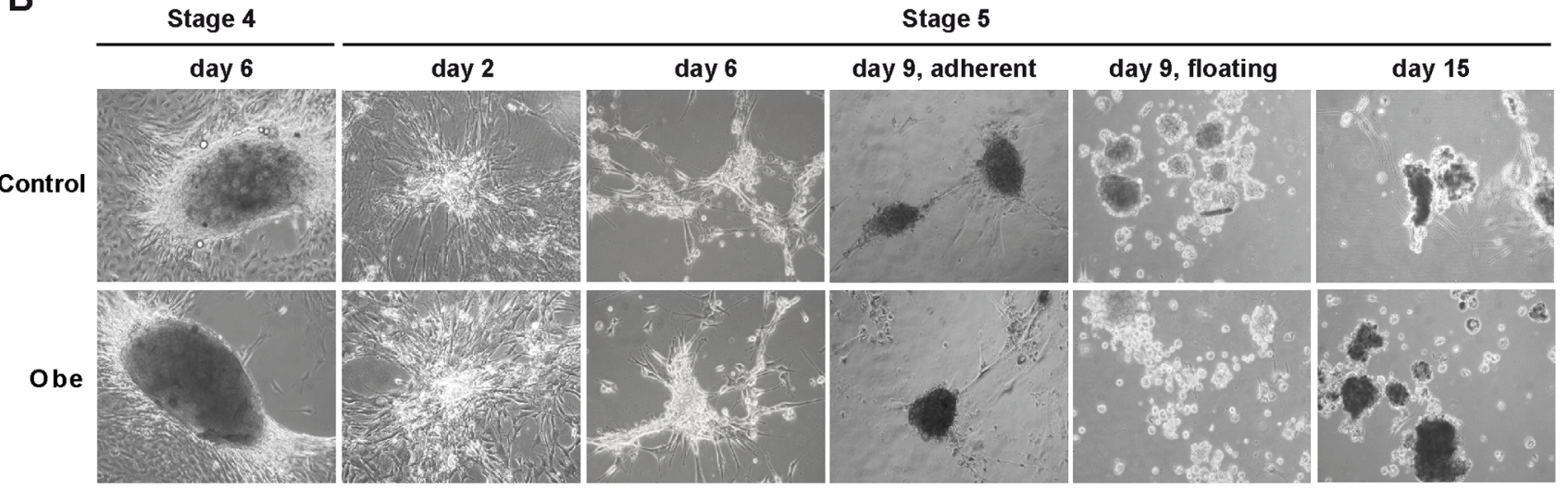

\begin{tabular}{|c|c|c|c|}
\hline & Stage 4, day 6 & Stage 5, day 9 & Stage 5, day 15 \\
\hline \multicolumn{4}{|c|}{ Mean islet area $\left(\mu m^{2}\right)$} \\
\hline Control & $12100 \pm 1300$ & $3640 \pm 200$ & $3260 \pm 340$ \\
\hline Obe & $16270 \pm 1500^{*}$ & $1770 \pm 100^{\star \star}$ & $2830 \pm 239$ \\
\hline \multicolumn{4}{|c|}{ Number of ditizone positive islets } \\
\hline Control & $44.3 \pm 8.5$ & $1056 \pm 89$ & $688 \pm 276$ \\
\hline Obe & $44.5 \pm 7.3$ & $1776 \pm 450^{*}$ & $1439 \pm 109^{* *}$ \\
\hline
\end{tabular}

Figure 1. Overview of culture evolution. For details also see Materials and Methods. (A) Schematic representation of the protocol used to obtain ICCs from mouse pancreas. Stage 1, pancreas removal; stage 2, pancreas digestion and plating; stage 3, islet enrichment; stage 4, islet adhesion and MLC appearance; stage 5, MLC migration, clustering and ICC formation. (B) Representative photomicrographs comparing the evolution of control and obestatin-treated (Obe) cultures. Islet adhesion to the plate induced generation of MLCs (stage 4). During stage 5 MLCs migrate and assemble to form ICCs. Magnification, 10X. (C) Mean surface area and number of adherent islets (stage 4 day 6 ) and floating ICCs (stage 5) in either control or obestatin treated conditions. Results are the mean \pm SEM. ${ }^{*} P<0.05,{ }^{*} P<0.01$ vs. control; $\# \# P<0.01$ vs. same condition at stage 4 , day 6 . $\mathrm{N}=6$. doi:10.1371/journal.pone.0064374.g001

\section{Immunofluorescence Analysis}

For differentiation markers, islets/cells were grown on coverslips, fixed in ice-cold 4\% paraformaldehyde (PFA) and processed as described [22]. Antibodies used: rabbit polycolonal antibody for nestin (1:100), Oct3/4 (1:80), Ngn3 (1:100), PDX1 (1:800), glucagon (1:100), somatostatin (1:100), ghrelin (1:100), rhodamine-labeled anti-ghrelin and anti-somatostatin (both 1:100); guinea pig serum anti-insulin (1:80); Alexa-488-conjugated antibodies $(1: 450)$. For cell proliferation, $\operatorname{BrdU}(10 \mu \mathrm{M})$ was added to cells at day 3 of stage 4 and at day 6 of stage 5 . After $72 \mathrm{~h}$ cells were fixed, treated with $2 \mathrm{~mol} / \mathrm{L} \mathrm{HCl}$ for $45 \mathrm{~min}$ at room temperature, neutralized with $0.1 \mathrm{~mol} / \mathrm{L}$ sodium borate $(\mathrm{pH} 8.5)$ for $15 \mathrm{~min}$ and processed for staining. Alexa-546 labeled antiBrdU antibodies (1:50) were used to assess BrdU incorporation. BrdU positive cells and nuclei were counted (100 to 500 cells) in 20 microscopic fields (X20). TAMRA-obestatin (TAMRA-Obe), was used to visualize obestatin binding in adherent islets and MLCs on coverslips as described [22]. For GPR39 and GLP-1R, cells were permeabilized with $0.2 \%$ Triton $\mathrm{X}-100$ after fixation, blocked in $10 \%$ goat serum, stained overnight with rabbit polyclonal antiGPR39 (1:150) or anti-GLP-1R (1:100) and incubated $1 \mathrm{~h}$ at room temperature with Alexa-488-conjugated goat anti-rabbit antibody (1:450). Nuclei were stained with DAPI. The same procedure was followed for TAMRA-obestatin co-localization with nestin. Images were taken using a Leica DM200 fluorescent microscope and a Leica DFC340 FX camera. For FGF2, cultures were FGF2starved for $2 \mathrm{~h}$ or not, fixed in ice-cold $4 \%$ PFA, then treated as described [22]. Anti-FGF2 was used at 1:100 for $2 \mathrm{~h}$ at room temperature. 100 to 500 nuclei were counted in 10 microscopic fields.

\section{Western Blotting}

Immunoblot analysis were performed as described [22]. Antinestin antibody was used at 1:500. Blots were reprobed with $\beta$ actin $(1: 2000)$ for normalization. Immunoreactive proteins were visualized with Chemidoc XRS (Bio-Rad, Milan, Italy), and 

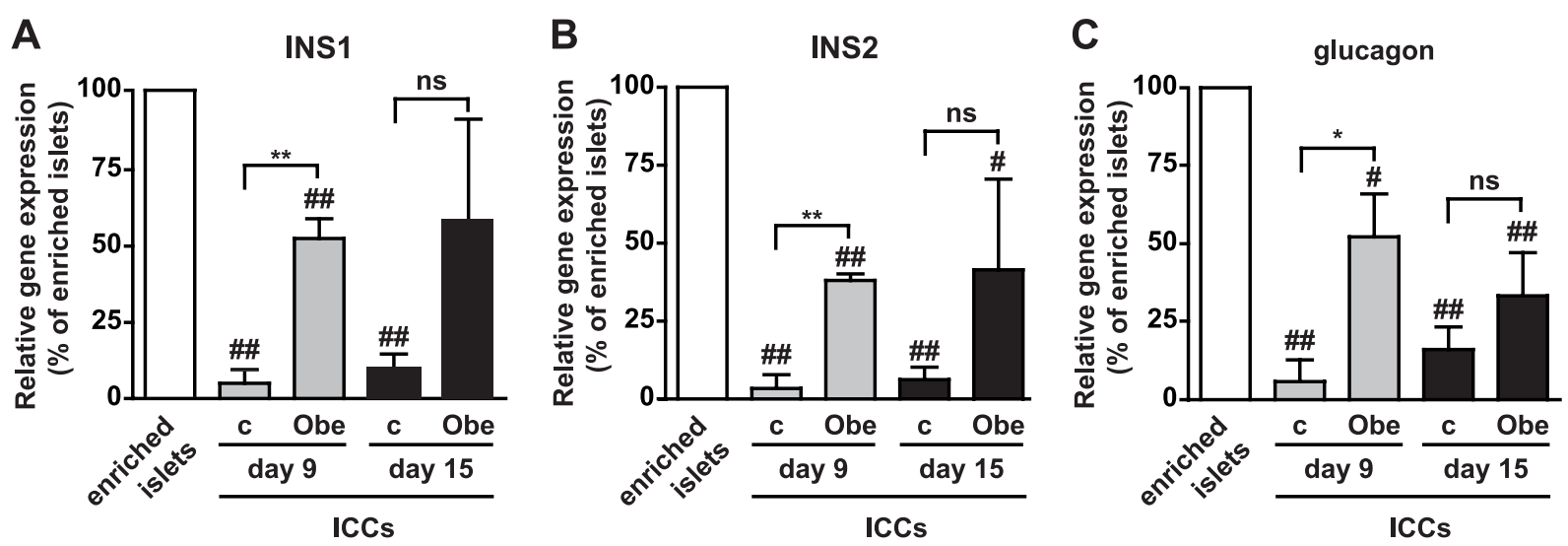

Figure 2. Obestatin up-regulates insulin and glucagon gene expression. INS1 (A), INS2 (B) and glucagon (C) mRNA expression in enriched islets and ICCs at day 9 and day 15 (stage 5) in control (c) and obestatin-treated (Obe) cultures evaluated by Real Time PCR. Gene expression was normalized to $\beta$-actin and reported as percent of enriched islets. ${ }^{*} P<0.05,{ }^{* *} P<0.01$ vs. $c_{;}{ }^{\#} P<0.05,{ }^{\# \#} P<0.01$ vs. enriched islets. $N=4$ (ns, not significant).

doi:10.1371/journal.pone.0064374.g002

densitometric analysis performed with Quantity One software (Bio-Rad).

\section{Glucose Levels and Protein Content}

Glucose was measured in cell conditioned medium $(300 \mu \mathrm{l})$. Samples were frozen at $-80 \mathrm{C}$ and quantified with the GLUGPAP kit (Menarini, Florence, Italy), according to manufacturer's instructions. Protein concentrations were determined with BCA Protein Assay Kit (Thermo Scientific, Pierce, Milan, Italy).

\section{Statistical Analysis}

Data are presented as means \pm SEM. Results were analyzed using 2-tailed Student's t test or two-way ANOVA followed by Tukey's HSD for post-ANOVA comparisons (GraphPad Prism 5.0 software, San Diego, CA). Significance was established when $P<0.05$.

\section{Results}

\section{Obestatin Influences ICC Number and Size}

Pancreatic islets were isolated and enriched (stage 1-3), then cultured for 6 days in serum-containing medium (stage 4), in either absence or presence of obestatin (Fig. $1 A$ and $B$ ). Most of dithizone ${ }^{+}$ islets attached to the plate, flattened and generated rapidly proliferating MLCs (Fig. 1A and B). At day 6 (stage 4) obestatintreated adherent islets displayed increased area with respect to control islets (Fig. 1C). At this stage, both untreated and obestatintreated islets showed expression of GPR39 and GLP-1R, as assessed by RT-PCR and immunofluorescent staining (Fig. S1).

The change to serum-free medium (stage 5) caused MLC migration away from the original islet. By day 6 (stage 5) they initiated aggregation into tridimensional structures (Fig. 1A and B) and at day 9 both adherent MLCs and early floating ICGs were observed (Fig. 1B). Most of MLCs assembled into ICCs by day 15 (Fig. 1A and B). At day 9 (stage 5), obestatin treatment reduced ICC area, whereas increased ICC number, with respect to control (Fig. 1C). At day 15 ICG area was comparable between control and obestatin-treated, although obestatin still increased ICC number (Fig. 1C). Compared to adherent islets (stage 4, day 6) ICG size was strongly reduced, whereas ICG number increased, in both obestatin-treated or control (Fig. 1C).

\section{Obestatin Increases Insulin and Glucagon Expression in ICCs}

Obestatin effects were investigated on insulin and glucagon mRNA expression in ICCs, at day 9 and 15 (stage 5). ICCs displayed lower insulin (INS1, INS2) and glucagon at either day 9 or 15 as compared to enriched islets. Notably, obestatin upregulated INS1, INS2 and glucagon mRNA at day 9 with respect to control, but not at day 15 (Fig. 2A-C). Enriched islets, ICCs at day 9 , but also at day 15 , were positive to insulin and glucagon also at protein level (Fig. 3A and B). Obestatin-treated ICGs displayed enhanced insulin staining at day 9 and 15 and greater glucagon expression at day 9 compared to control. At day 15, instead, glucagon was barely detectable in both conditions (Fig. 3B). Enriched islets were positive for somatostatin (SST) at protein level (Fig. 3A). Conversely, no gene and protein expression for SST in ICCs, and for ghrelin in enriched islets and ICCs, was detected. Enriched islets also expressed PDX1, a $\beta$-cell progenitor marker [3,6,11] (Fig. 3A). Few cells in the islets expressed neurogenin 3 (Ngn3), marker of endocrine-committed pancreatic progenitors [28], but none expressed the stem cell marker octamer-binding transcription factor 4 (Oct4) [3] (Fig. 3A). Furthermore, islets were negative for the pancreatic duct marker cytokeratin 19 (Cyto19) [8], suggesting absence of duct contamination (Fig. 3A).

\section{Obestatin Enhances Glucose-stimulated C-peptide Secretion in ICCS}

Cells grown in insulin-containing medium may take-up and release exogenous insulin or display insulin immunoreactivity without real endocrine differentiation [29]. Therefore, glucosestimulated insulin secretion was determined (Fig. S2A) and compared to insulin levels in cell culture medium (Fig. S2B). Obestatin-treated ICCs displayed the highest response at day 9, followed by control ICCs (Fig. S2A), whereas control ICGs at day 15 showed the lowest insulin secretion (Fig. S2A). In culture medium, insulin levels were sustained until day 6, indicating additional insulin secretion from residual $\beta$-cells, but decreased abruptly at day 9 when ICCs had formed, confirming uptake of exogenous insulin (Fig. S2B). Nonetheless, the difference in insulin release between control and obestatin-treated ICCs suggest de novo insulin synthesis, in line with the mRNA expression data (Fig. 2A and B). 
A
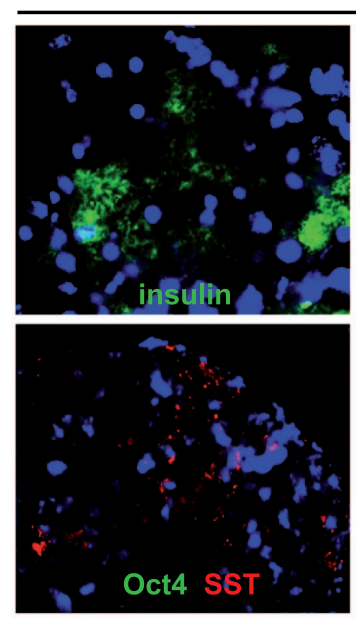

Enriched islets
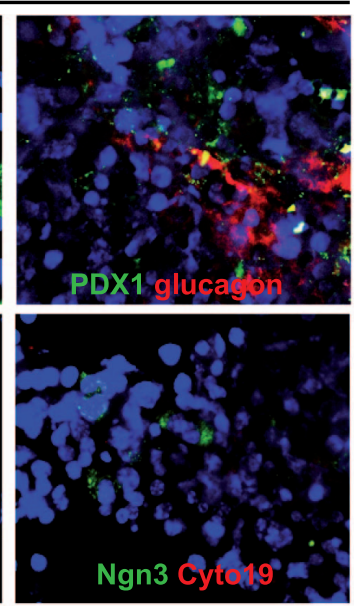

B
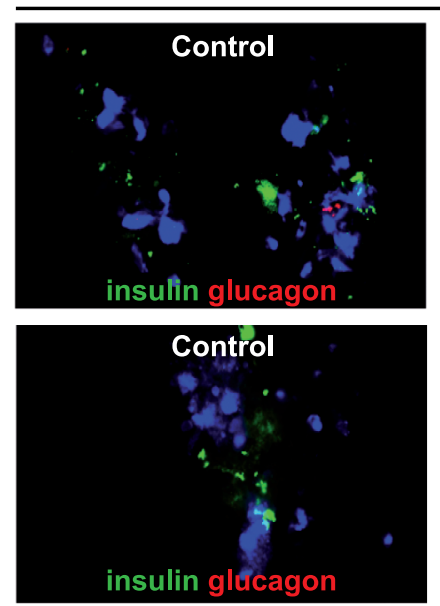

ICCs

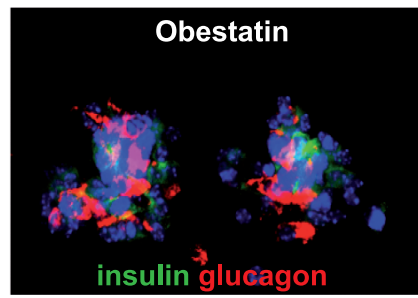

day 9

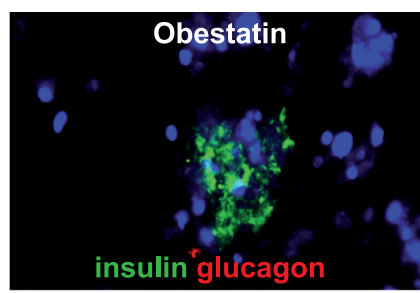

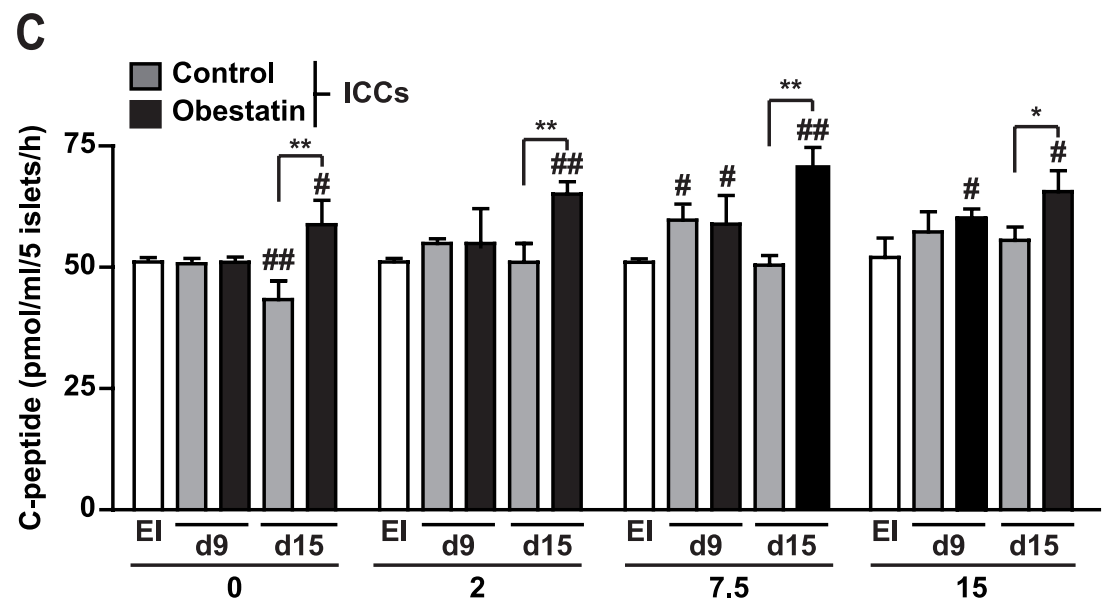

Glucose (mM)
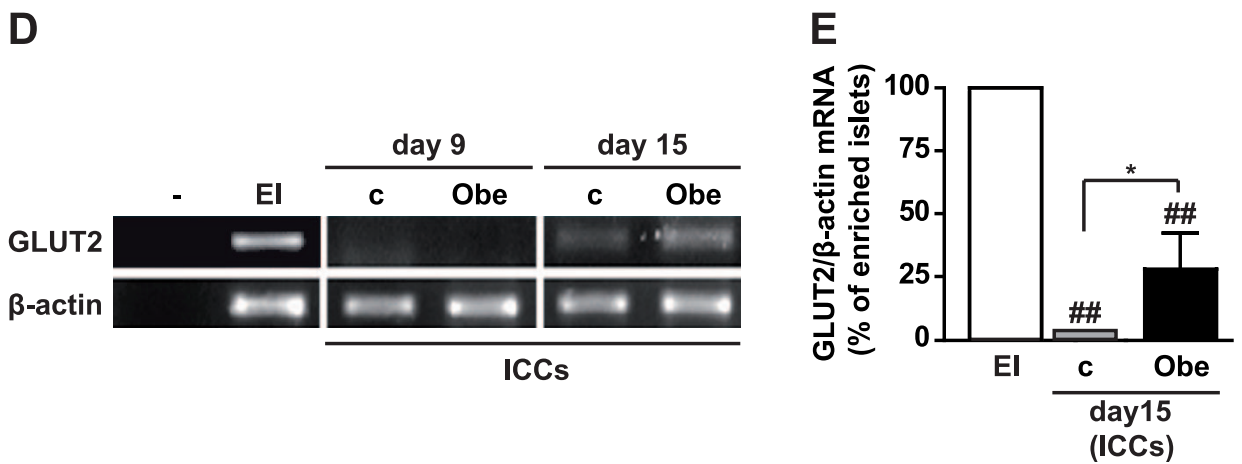

Figure 3. Differentiation markers and hormone expression in islets and ICCs and obestatin effects on C-peptide secretion. (A) Fluorescence microscopy images showing enriched islets stained for insulin, glucagon and somatostatin and the indicated markers of progenitors (magnification, X20). Cytokeratin 19 (Cyto19) was used as marker for pancreatic ducts. (B) Immunofluorescent staining for insulin and glucagon in ICCs formed in either absence (control) or presence of obestatin at the indicated days (magnification, X40). (C) C-peptide secretion, assessed by ELISA, from ICCs stimulated at either day 9 or day 15 with the indicated concentrations of glucose. Results are the mean \pm SEM of three different experiments performed in duplicate $\left({ }^{*} P<0.05,{ }^{* *} P<0.01\right.$ vs. control ICCs; ${ }^{*} P<0.05{ }^{\# \#} P<0.01$ vs. enriched islets, El). (D) GLUT-2 mRNA determined by RT-PCR. $\beta$-actin was used as housekeeping gene. Shown is a representative image of three independent experiments. Buffer alone was used as negative control $(-)$ (c, control, no obestatin). (E) Densitometric analysis of GLUT-2 mRNA normalized to $\beta$-actin and reported as percent of enriched

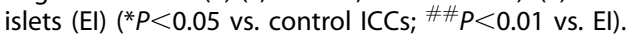

doi:10.1371/journal.pone.0064374.g003 
To confirm de novo insulin synthesis, C-peptide secretion [29,30] was measured in enriched islets and ICCs, either untreated or treated with obestatin. Basal C-peptide release in enriched islets was unchanged upon glucose-stimulated conditions, likely because of the strict extraction procedures (Fig. 3C). At day 9, control and obestatin-treated ICGs displayed comparable secretion. However, at day 15, obestatin strongly increased C-peptide release compared to control at all glucose concentrations (Fig. 3C), except at $25 \mathrm{mmol} / \mathrm{L}$ where glucose was likely cytotoxic (data not shown). In line with improved endocrine differentiation and/or glucose sensitivity, the $\beta$-cell glucose transporter 2 (GLUT2) mRNA was increased at day 15 compared to control in obestatin-treated ICGs, being barely detectable at day 9. Conversely, GLUT2 was strongly expressed in enriched islets (Fig. 3D and E).

\section{Obestatin Promotes the Increase of Nestin ${ }^{+}$Cells in Enriched Islets}

To elucidate the cellular/biological events underlying obestatininduced improvement of ICGs endocrine differentiation, we assessed proliferation of cells expressing the different hormones and differentiation markers $[3,6,11,28]$ at day 6 of stage 4 , before the progenitor selection phase. These included nestin, Oct4, PDX1 and Ngn3. Within the islet, nestin ${ }^{+}$cells were the prevalent population upon adhesion, independently of obestatin treatment (Table 1). Obestatin increased glucagon ${ }^{+}$cell number but decreased their proliferation, likely improving commitment of cells to the alpha type. Obestatin did not affect $\mathrm{Ngn}^{+}$cell proliferation, although reduced their percentage, suggesting differentiation into other cell types [28,31-33]. Conversely, obestatin increased insulin ${ }^{+}$cell number and proliferation, suppressed somatostatin expression and prevented $\mathrm{PDX}^{+}$and $\mathrm{Oct}^{+}$cell proliferation (Table 1).

Obestatin promoted late proliferation of few insulin ${ }^{+}$cells in MLCs (Table 2) and mildly increased ghrelin ${ }^{+}$cell number. It also caused disappearance of $\mathrm{Ngn}^{+}$cells. Most of all, obestatin strongly increased nestin ${ }^{+}$MLGs, that likely co-expressed other markers (Table 2) [3,13,34], although decreasing their late proliferation (Table 2). Despite these effects, obestatin did not influence total cell proliferation $\left(15.3 \pm 1.8 \mathrm{BrdU}^{+}\right.$cells in control islets vs. $15.2 \pm 0.1 \%$ in obestatin-treated islets, $14.2 \pm 2.2 \% \mathrm{BrdU}^{+}$ cells in control MLCs vs. $14 \pm 4.3 \%$ in obestatin-treated MLCs) and cell dimension (control, $14.9 \pm 1.39 \mu \mathrm{m}$; obestatin, $16.2 \pm 0.9 \mu \mathrm{m})$. These results confirm previously described mito-

Table 1. Enumeration of endocrine hormone-producing cells and $\mathrm{BrdU}^{+}$cells within the islet (day 6, stage 4).

\begin{tabular}{|c|c|c|c|c|}
\hline \multicolumn{3}{|c|}{ Total cells (\%) } & \multicolumn{2}{|c|}{ BrdU positive cells (\%) } \\
\hline \multicolumn{2}{|l|}{ Control } & \multirow{2}{*}{$\begin{array}{l}\text { Obestatin } \\
18.8 \pm 6.9^{*}\end{array}$} & \multirow{2}{*}{$\begin{array}{l}\text { Control } \\
51.5 \pm 1.5\end{array}$} & \multirow{2}{*}{$\begin{array}{l}\text { Obestatin } \\
57.4 \pm 2.6^{*}\end{array}$} \\
\hline Insulin & $3.5 \pm 1.9$ & & & \\
\hline Glucagon & $31.9 \pm 4.5$ & $40.5 \pm 2$ & $36.6 \pm 7$ & $14.1 \pm 5.1^{*}$ \\
\hline Ghrelin & $3.9 \pm 2.2$ & $1.8 \pm 0.2$ & $79.2 \pm 12$ & $78.4 \pm 12.5$ \\
\hline Somatostatin & $1.3 \pm 0.8$ & $0 \pm 0$ & $76.45 \pm 13.6$ & $0 \pm 0^{* *}$ \\
\hline PDX1 & $48.9 \pm 9.4$ & $48.3 \pm 13.2$ & $24.9 \pm 0.6$ & $8 \pm 3.6^{* *}$ \\
\hline Ngn3 & $26.2 \pm 9.1$ & $10.9 \pm 3.4^{*}$ & $45.1 \pm 14.6$ & $41.5 \pm 12.5$ \\
\hline Nestin & $65.4 \pm 11$ & $59.2 \pm 7.6$ & $18.2 \pm 7.5$ & $8.4 \pm 8.4$ \\
\hline Oct4 & $7.2 \pm 1.3$ & $5.7 \pm 1.3$ & $58.4 \pm 4.7$ & $2.5 \pm 2.5^{* *}$ \\
\hline
\end{tabular}

Results are the mean \pm SEM of three independent experiments $\left({ }^{*} P<0.05\right.$; ${ }^{*} \mathrm{P}<0.01 ; \mathrm{n}=3$ ).

doi:10.1371/journal.pone.0064374.t001
Table 2. Enumeration of endocrine hormone-producing cells and $\mathrm{BrdU}^{+}$cells (proliferating MLCs; day 6, stage 4).

\begin{tabular}{|c|c|c|c|c|}
\hline \multicolumn{3}{|c|}{ Total cells (\%) } & \multicolumn{2}{|c|}{ BrdU positive cells (\%) } \\
\hline Control & & Obestatin & Control & Obestatin \\
\hline Insulin & $5.4 \pm 2$ & $5.5 \pm 3$ & $18.9 \pm 10.6$ & $53.7 \pm 7.5^{*}$ \\
\hline Glucagon & $12.8 \pm 3.4$ & $11.1 \pm 5$ & $3.4 \pm 2.3$ & $0 \pm 0$ \\
\hline Ghrelin & $0.27 \pm 0.27$ & $3.1 \pm 0^{* *}$ & $0 \pm 0$ & $0 \pm 0$ \\
\hline Somatostatin & $0.4 \pm 0.4$ & $2.4 \pm 2.4$ & $0 \pm 0$ & $4 \pm 4$ \\
\hline PDX1 & $13 \pm 3.7$ & $11.4 \pm 3.6$ & $12.2 \pm 7$ & $9.3 \pm 4$ \\
\hline Ngn3 & $15 \pm 10.6$ & $0 \pm 0^{* *}$ & $48.5 \pm 2.3$ & $0 \pm 0^{* *}$ \\
\hline Nestin & $20.6 \pm 8.8$ & $97.5 \pm 2.5^{* *}$ & $52.5 \pm 14$ & $21.9 \pm 0.7^{*}$ \\
\hline Oct4 & $12.8 \pm 6$ & $2.8 \pm 2.39$ & $21.6 \pm 14.1$ & $10 \pm 10$ \\
\hline
\end{tabular}

Results are the mean \pm SEM of three independent experiments $\left({ }^{*} P<0.05\right.$; **P $<0.01 ; \mathrm{n}=3$ ).

doi:10.1371/journal.pone.0064374.t002

genic effects on $\beta$-cells [21] and suggest that obestatin enriches nestin $^{+}$MLCs and negatively modulates Ngn3 expression at stage 4.

Obestatin Binds to Adherent Islets, MLCs and Neuronallike Nestin ${ }^{+}$cells at the End of Stage 4

In line with the increased percentage of nestin ${ }^{+}$MLCs (Table 2), obestatin up-regulated nestin gene expression and protein at the end of stage 4 (Fig. 4A and B). Therefore, we investigated whether obestatin may directly bind to MLCs and islets. At day 6 of stage 4, TAMRA-obestatin (T-Obe) stained adherent islets and also the soma of nestin ${ }^{+}$neuronal-like cells, in both control and obestatintreated cultures (Fig. 4C and D). T-Obe binding was observed in the majority of obestatin-treated nestin ${ }^{+}$MLCs, compared to control MLCs (Fig. 4E).

\section{Obestatin Reduces Apoptosis during ICC Formation at Stage 5}

Serum-free medium switch at the end of serum-stimulated cell growth was shown to cause apoptosis selection and expansion of pancreatic progenitors $[11,15,35,36]$. We monitored cell survival and apoptosis at day 2 and 6 (stage 5) when most cells were still adherent. Protein content in control cultures dramatically decreased at day 2 and 6 of stage 5, returning to values close to day 0 (i.e. day 6 of stage 4 ) only from day 9 (Fig. 5A). Conversely, in obestatin-treated cultures, protein content was unchanged with respect to day 0 , suggesting increased cell viability (Fig. 5A). Cell survival was reduced at day 2 and even more at day 6 as compared to day 0 (Fig. 5B) and was increased by obestatin at day 6 (Fig. 5B). Obestatin inhibited apoptosis at day 2 compared to control (Fig. 5C). At day 6, apoptosis was halved in control cells, suggesting that cell selection was complete [11]; however, obestatin still displayed antiapoptotic actions (Fig. 5C).

\section{Obestatin Reduces FGF2-induced Cell Migration of MLCs at Stage 5}

At stage 5, FGF2 in the medium is initially required for selection of pancreatic progenitors $[11,15,35,36]$ and later, to initiate their endocrine differentiation [37]. FGF2 also plays a role in precursor cell migration and aggregation into ICCs [37]. We investigated FGF2 effect on cell migration in obestatin-treated MLCs at day 2 and 6, when most cells were still adherent. At day 2, FGF2 
A

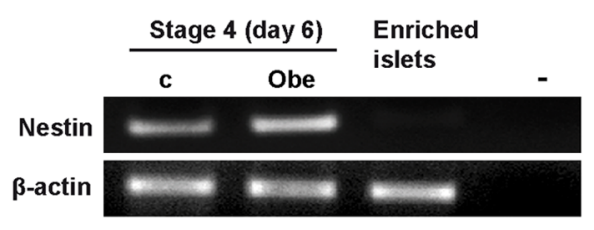

B

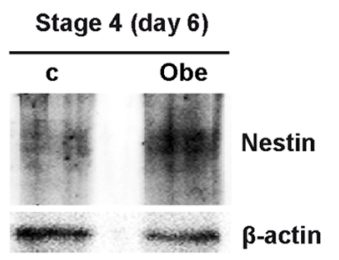

C
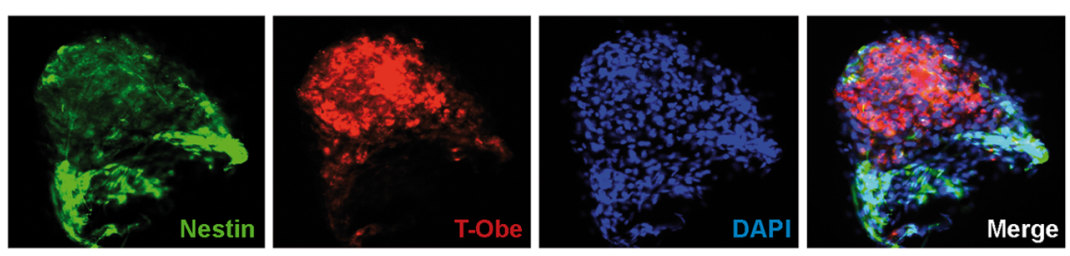

D
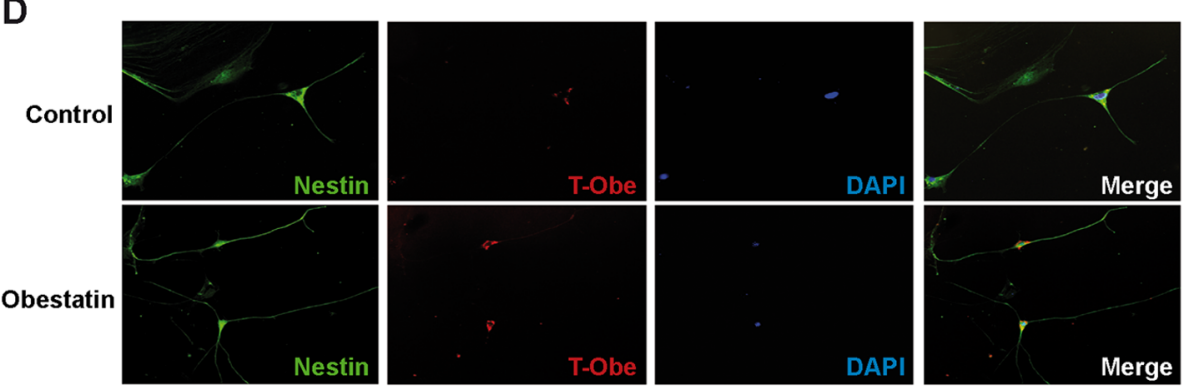

E
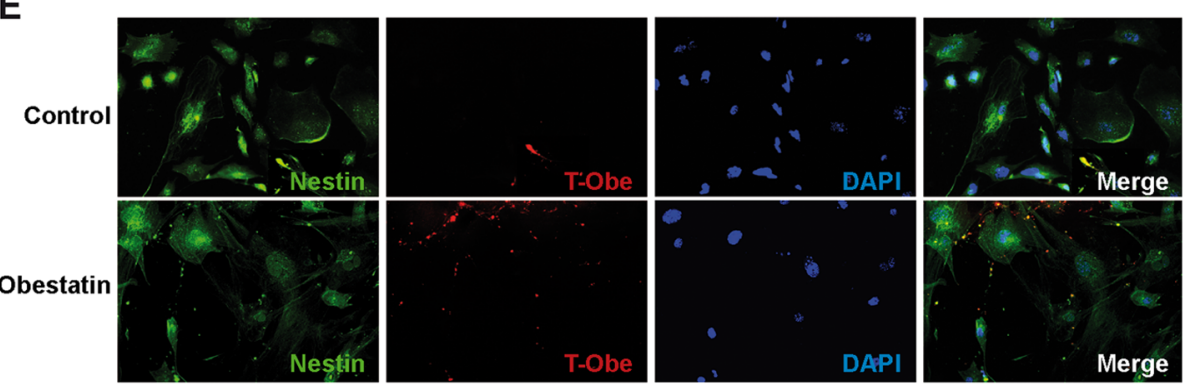

Figure 4. Obestatin up-regulates nestin expression at stage 4 and binds to enriched islets and MLCs. (A) Nestin mRNA assessed by RTPCR in control (c) and obestatin-treated cells (Obe). Buffer alone was used as negative control (-). Shown is a representative image of three independent experiments. (B) Nestin protein expression determined by Western blot in lysates cultures that were either untreated or treated with obestatin $(n=3)$. (C) TAMRA-Obestatin (T-Obe) $(1 \mu \mathrm{M})$ binding to adherent islets and emerging MLCs. The image is representative of both untreated and obestatin-treated cultures, that were tested in at least three independent experiments (magnification, X20). (D-E) T-Obe (1 $\mu$ M) binding to nestin $^{+}$neuronal-like cells (D) and to Nestin ${ }^{+}$MLCs (E) in both control and obestatin-treated cultures $(n=3$; magnification, X40). T-Obe is shown in red, nestin in green and nuclei in blue (DAPI).

doi:10.1371/journal.pone.0064374.g004

strongly increased cell migration in cells cultured in the absence of obestatin (control). This effect was inhibited by an FGF2neutralizing antibody, suggesting specificity (Fig. 6A). Conversely, obestatin strongly increased MLC basal migration at day 2, but no additional effect was displayed by FGF2 and its neutralizing antibody (Fig. 6A). At day 6, the FGF2 stimulatory effect on control cell migration was specific and similar to day 2 (Fig. 6B). Instead, obestatin-treated cultures showed dramatically reduced basal migration compared to control cells. Moreover, although FGF2 increased migration, the neutralizing antibody was ineffective, suggesting non specific FGF2 action (Fig. 6B). The different results obtained at day 2 and 6 were independent of cell size, which was similar in control and obestatin-treated cells (day 2, control: $18.6 \pm 1.3 \mu \mathrm{m}$, obestatin: $20.8 \pm 1.7 \mu \mathrm{m}$; day 6 , control: 19.2 $\pm 0.6 \mu \mathrm{m}$, obestatin: $17.4 \pm 1 \mu \mathrm{m})$.

\section{Obestatin Reduces FGF Receptor Expression and FGF2 Binding at Stage 5}

To further understand obestatin effects on FGF2 altered sensitivity, we evaluated the expression of FGF2 and its receptors (FGFRs). Both control and obestatin-treated cultures showed comparable FGF2 gene expression at day 2, 6 and 9 (Fig. 6C), in agreement with endogenous FGF2 immunoreactivity in FGF2starved cells. Conversely, at day 2 obestatin down-regulated FGFR3 and FGFR4 mRNA compared to control (Fig. 6C). At day 6, FGFR mRNA levels in control and obestatin-treated cultures were similar, except for FGFR2c that was slightly down-regulated by obestatin. At day 9, obestatin-treated cultures displayed reduced FGFR2b, FGFR2c and FGFR4 expression compared to control (Fig. 6C), in line with endocrine differentiation [37]. No change over time and treatment was detected for FGFR1 mRNA 
A

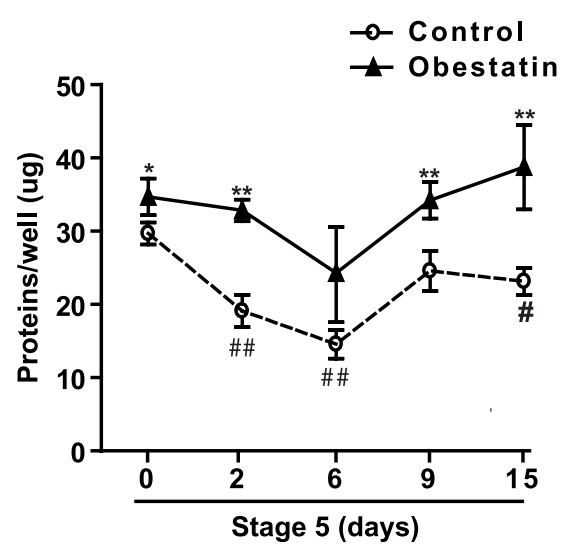

B

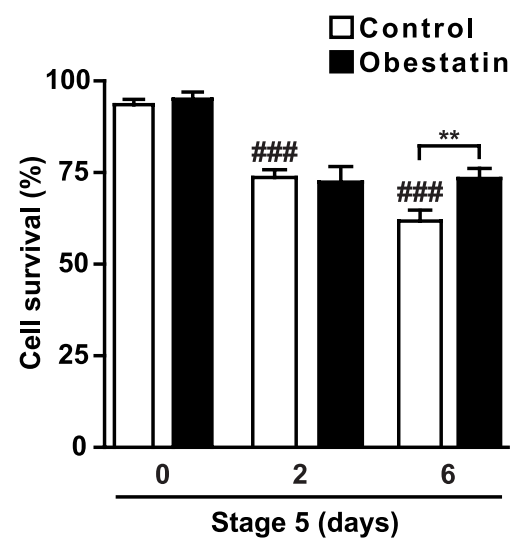

C

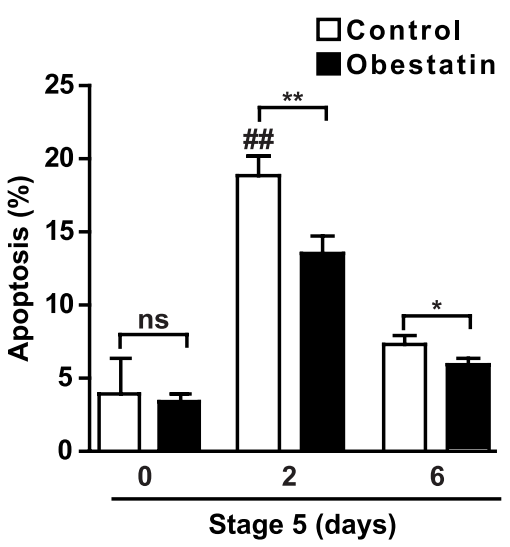

Figure 5. Obestatin promotes cell survival and decreases serum starvation-induced apoptosis at stage 5. (A) Protein content in control and obestatin-treated cultures at the indicated days. (B-C) Cell survival (B) and apoptosis (C) assessed by Trypan blue exclusion and Hoechst 33258 staining, respectively, at the indicated days. For all graphs, results are the mean \pm SEM of three independent experiments $\left({ }^{*} P<0.05\right.$, ${ }^{* *} P<0.01$ vs. control; ${ }^{\#} P<0.05,{ }^{\# \#} P<0.01,{ }^{\# \# \#} P<0.001$ vs. day 0 ).

doi:10.1371/journal.pone.0064374.g005

(Fig. 6C). FGFR gene expression decrease may in part be involved in the different migratory profile of obestatin-treated cells (Fig. 6A and $\mathrm{B}$ ). To determine this, we compared control and obestatintreated MLC ability to bind to FGF2. FGF2 immunoreactivity was assessed in cells cultured in normal conditions (FGF2-containing medium). At day 2, FGF2 positivity was strongly reduced in obestatin-treated cells compared to control, whereas at day 6 and at day 9, it was similar between control and obestatin-treated MLCs (Fig. 6D). Similar results were obtained in FGF-starved conditions (Fig. S3). The apparent discrepancy between receptor expression in the whole culture (Fig. 6C) and of FGF2 binding in obestatin-treated MLCs at day 9 (Fig. 6D), may depend on the presence of differentiated ICGs in obestatin-treated cultures. Indeed, at the periphery of obestatin-treated MLC clusters and in the central ICG-forming region, FGF2 binding was decreased with respect to control MLCs (Fig. 6D and S3).

\section{Obestatin Down-regulates Notch Receptor Gene and Up-} regulates Ngn3 Gene and Protein Expression at Stage 5

FGFRs stimulation in pancreatic precursor cells maintains active Notch signaling and inhibits Ngn3 expression and endocrine differentiation $[28,38]$. While data on Notch ligands Jagged 1,2, Delta-like 1, 3 and 4 expression were inconsistent, expression of Notch receptors varied during stage 5 (Fig. 7A). Obestatin reduced Notch 1, 2 and 3 expression at day 2, and Notch 1, 3 and 4 at day 6. Conversely, it increased Notch 1 and 3 at day 9 (Fig. 7A). Ngn3 gene expression increased at day 6 with respect to day 2 in both control and obestatin-treated cultures, suggesting MLC commitment toward endocrine differentiation (Fig. 7A). As Ngn3 decreases at the end of differentiation, we hypothesized that inclusion of ICCs in gene expression analysis at day 9 would mask Ngn3 differential expression in control and obestatin-treated MLCs. Indeed, we found that Ngn3 in obestatintreated MLCs at day 9 was increased vs. control (Fig. 7B). Moreover, immunofluorescence studies showed that, whereas in control cultures Ngn3 positivity was low and mainly localized outside the nuclei, in obestatin-treated MLCs Ngn3 was high and mainly nuclear (Fig. 7C, monolayer). Moreover, Ngn3 expression in cells acquiring tridimensional shape was greater in obestatintreated MLCs compared to control (Fig. 7C, clustered). These results suggest that obestatin modulates Notch receptors and upregulates Ngn3 gene and protein in MLCs during ICG formation. Table S2 shows the percentage and proliferation rate of MLCs expressing the different hormones and differentiation markers at day 9 of stage 5 . Residual MLCs on the plate were either sparse or clustering to form additional ICCs. All hormones and markers were highly expressed, especially glucagon, but not insulin, in line with appearance of $\beta$-cells following that of $\alpha$-cells $[28,39]$. Obestatin also decreased somatostatin ${ }^{+}$cell number and proliferation and inhibited $\mathrm{Ngn}^{+}$cell proliferation, suggesting commitment of $\mathrm{Ngn}^{+}$cells toward differentiation (Table S2).

\section{Discussion}

This study shows obestatin effects on in vitro generation of ICCs from islet-derived MLCs. Insulin and glucagon gene expression and glucose-stimulated C-peptide secretion were increased in obestatin-treated ICGs as compared to control. Improved in vitro ICC endocrine differentiation may be explained by obestatininduced down-regulation of FGFRs, selective modulation of Notch receptors and timely induction of Ngn3.

Pancreatic $\beta$-cells obtained from human and rodent isletderived pancreatic progenitors have shown deficient insulin synthesis and glucose-induced insulin/C-peptide secretion $[1,11,12,14,15,40]$. These limits have been recently improved by supplementation with growth factors involved in pancreas regeneration and function $[3-5,7,9]$. Here, obestatin increased insulin gene expression in ICGs at day 9 to $30-50 \%$ of enriched islets, a remarkable improvement compared to control ICGs and to previous findings [1,11-15]. Furthermore, glucose dependent C-peptide secretion and enhanced GLUT-2 expression in obestatin-treated ICGs suggested efficient MLC differentiation into $\beta$-cells at day 15. Generation of more functional ICGs involves obestatin binding to adherent islets and nestin ${ }^{+}$MLCs, enrichment of nestin ${ }^{+}$MLCs, reduction of apoptosis and increased MLC survival. Thus, mainly in nestin ${ }^{+}$MLCs, obestatin might stimulate endocrine differentiation.

Besides obestatin, another major difference from previous protocols $[11,14,15]$ is that here the cells were never detached from the original plate, to avoid cell death and quiescence. The 
A

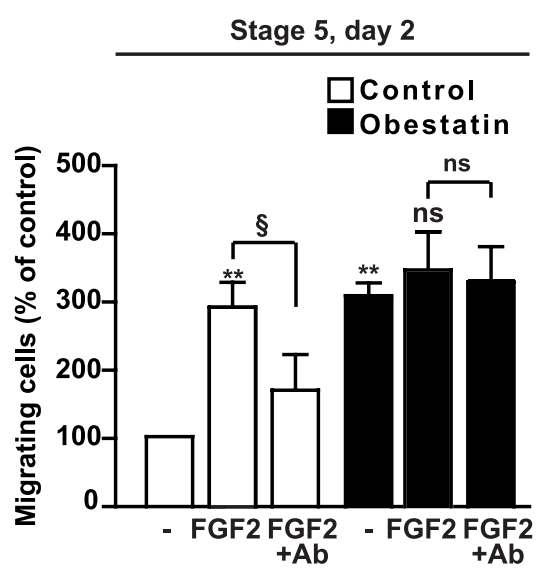

B

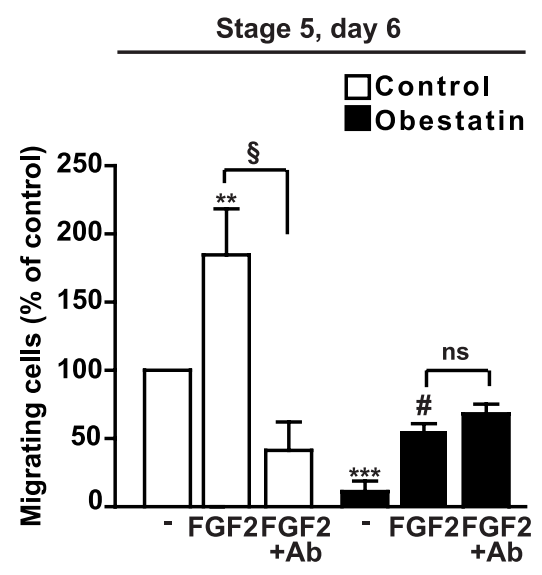

C

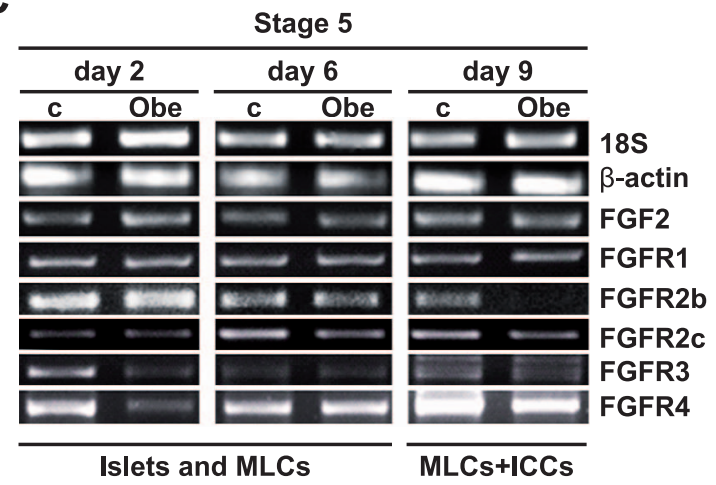

D

MLCs (stage 5)

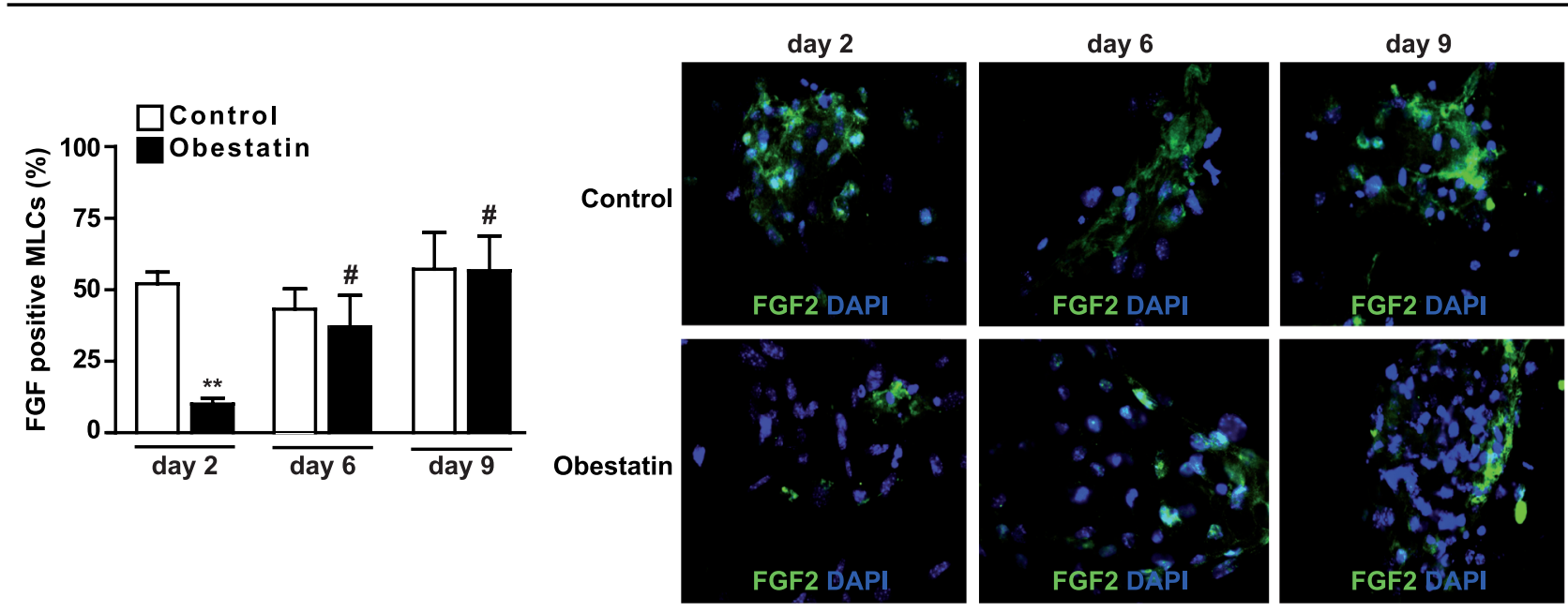

Figure 6. Obestatin inhibits cell migration and FGF2 binding to MLCs at stage 5. (A-B) Basal and FGF2-induced cell migration assessed at day 2 (A) and 6 (B) in either untreated cells (Control) or obestatin-treated cultures (-, no FGF2). Neutralizing antibody against FGF2 (Ab) was used to verify the specificity of FGF2 effect. The cells were deprived of FGF2 for $12 \mathrm{~h}$ then exposed for $4 \mathrm{~h}$ to $100 \mathrm{ng} / \mathrm{ml}$ of FGF2 and $100 \mathrm{ng} / \mathrm{ml}$ of neutralizing antibody. Results are the mean \pm SEM of three independent experiments performed in duplicate $(* * P<0.01, * * * P<0.001$ vs. control; ${ }^{\#} P<0.05$ vs. $-;{ }^{\S} P<0.05,{ }^{\S \S} P<0.01$; ns, not significant). (C) Expression of FGF2 and FGFRs assessed by RT-PCR at the indicated days in control (c) and obestatin-treated cultures (Obe). Results are representative of three independent experiments. (D) FGF2 ${ }^{+}$MLCs that were cultured in non FGF2starved conditions, in either absence or presence of obestatin at the indicated days. Results shown in the graph (left) are expressed as percent of total cell number and are the mean \pm SEM of three independent experiments performed in duplicate ${ }^{* *} P<0.01 \mathrm{vs}$. control, ${ }^{*} P<0.01 \mathrm{vs}$. obestatin at day 2). Right panel, representative images (X20) of FGF2 staining (green) $(n=3)$; nuclei are shown in blue (DAPI). doi:10.1371/journal.pone.0064374.g006 
A

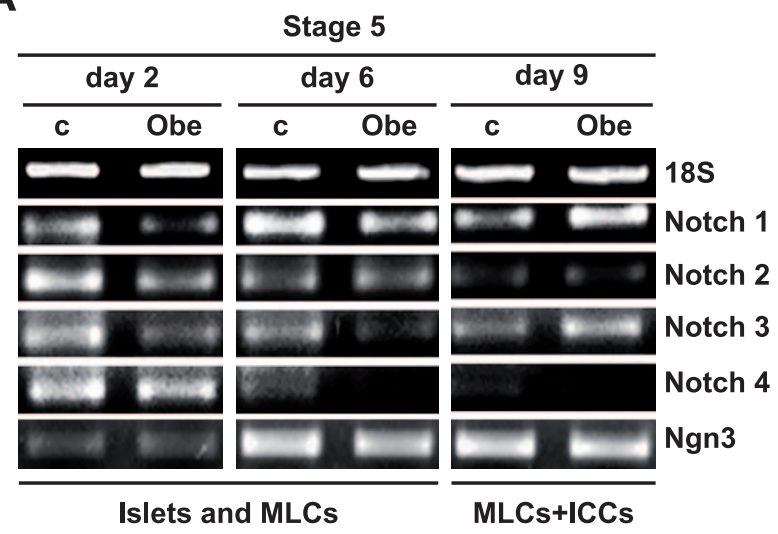

Stage 5, day 9

B

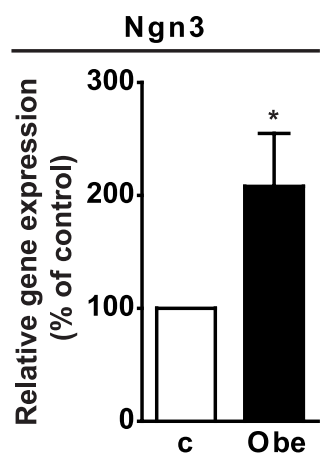

C

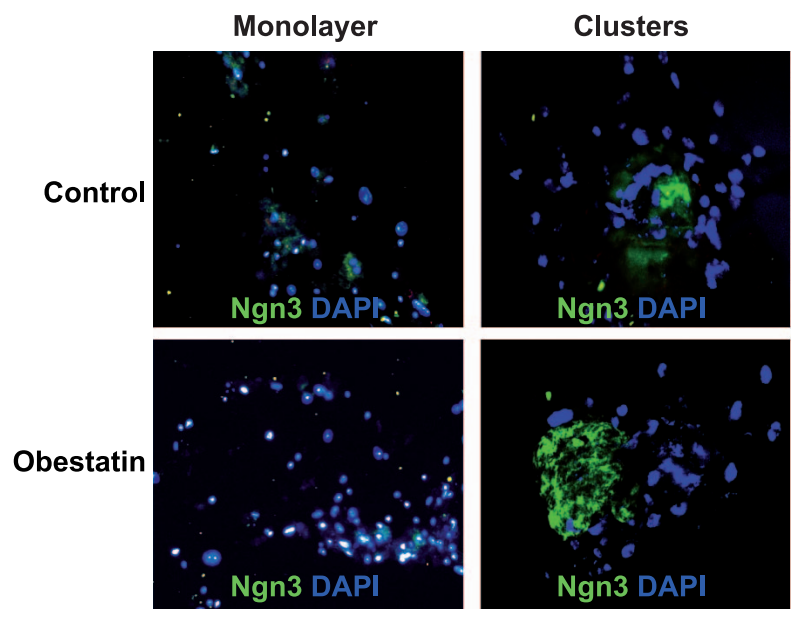

D

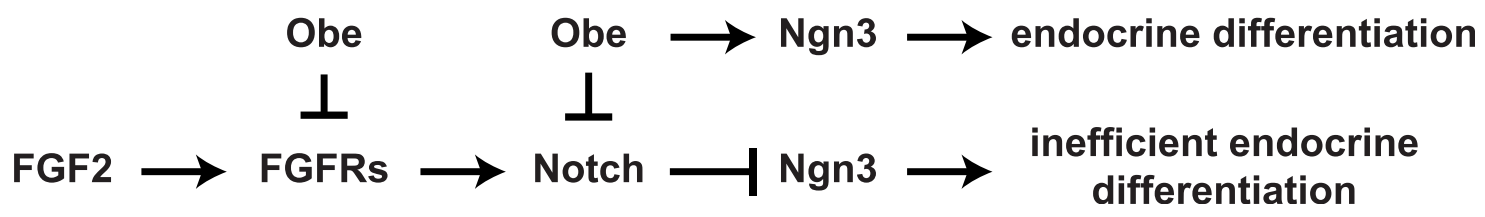

Figure 7. Obestatin modulates Notch receptors and Ngn3 gene expression. (A) RT-PCR analysis showing Notch receptors and Ngn3 mRNA at the indicated times in control (c) and obestatin-treated (Obe) cultures. Results are representative of three independent experiments. (B) Ngn3 mRNA assessed by real-time PCR at day 9 of stage 5 in adherent MLCs. Results are the mean \pm SEM of three independent experiments performed in duplicate $\left({ }^{*} P<0.05\right.$ vs. control). (C) Immunofluorescent staining for Ngn3 in adherent cells (monolayer) (X20) and clustered cells (X40), in both control and obestatin-treated cultures. Ngn3 is shown in green and nuclei in blue (DAPI). Each image is representative of three independent experiments. (D) Schematic illustration of obestatin mechanisms of action. During pancreatic development FGF2 promotes pancreatic precursor cell proliferation through FGFRs, inducing Notch signaling and preventing Ngn3 expression. Upon serum removal, FGF2 promotes MLC proliferation and Notch receptors expression. Obestatin treatment inhibits FGF2 action by reducing expression of FGFRs. Obestatin also inhibits the expression of selective Notch receptors, leading to increased Ngn3 expression and endocrine differentiation. doi:10.1371/journal.pone.0064374.g007

older age of mice (six/seven months) may explain this reduced cell viability and $\beta$-cell proliferation [41]. Moreover, the reservoir of non differentiated cells is likely restricted to those eventually implicated in pancreatic regeneration $[7,8,10,42]$ and $\beta$-cell survival [10]. Here, our cell separation-free protocol, where MLCs were maintained with their 'mother' islets, may have better 
mimicked the in vivo condition, being less harmful to residual precursors $[7,8,10,43]$. This culture method may not provide a renewable supply of ICGs; however, previous studies demonstrated that ICGs may be replated to generate novel MLCs and ICGs [13]. Additional studies will clarify whether obestatin-treated ICCs display increased survival and growth, and achieve the functional complexity of an islet once transplanted in vivo $(4,5)$. Our findings may help improving the current protocols for in vitro $\beta$-cell regeneration and suggest that endogenous/exogenous obestatin influences pancreas regeneration and development. Interestingly, enriched islets expressed here PDX1 and Ngn3, both involved in pancreas regeneration $[7,42]$.

In vivo, blockade of FGF-FGFRs signaling causes disruption of precursor cell proliferation, untimely endocrine differentiation and impaired pancreas organogenesis $[35,38,44,45]$. Obestatin selectively reduced FGFR expression. Moreover, obestatin altered cell response to FGF2, a mitogen for nestin ${ }^{+}$mesenchymal stem cells and pancreatic progenitors $[15,35,36]$ and chemoattractant for pancreatic progenitors [37], such that FGF2 failed to induce migration in obestatin-treated cells. This occurred at day 2 when FGFR3 and FGFR4 were down-regulated, and at day 6, when FGF2 binding and FGFR expression were similar to untreated MLCs.

Here, we found that FGF2 migratory effects were blocked by a specific anti-FGF antibody in control but not in obestatin treated cells. This may be interpreted as i) an FGF2-independent migration of obestatin treated cells at day 2, when the expression of FGFR specific isoforms was reduced, ii) a partial recovery of FGF2-induced migration in obestatin treated cells at day 6 , when expression and binding of FGFRs returned similar to control cells. In both cases, the lack of effect of the neutralizing antibody in obestatin treated cells may be due to the existing difference in the pool of receptor-associated/modulating proteins with respect to control, such that formation of an FGF2-antibody complex may not prevent binding of FGF2 to its receptor.

As inhibition of FGFR2b and FGFR2c, the most FGF2sensitive isoforms, has been associated to incorrect pancreas organogenesis and early endocrine differentiation $[37,45,46]$, obestatin-induced down-regulation of FGFR2b and FGFR2c at day 9 may relate to advanced endocrine differentiation. Moreover, the small obestatin-induced FGFR2c down-regulation at day 6 suggests that endocrine differentiation starts earlier, in line with decreased MLC basal migration.

FGFR3 blockade in vivo causes increased proliferation of immature pancreatic epithelium and islet precursors [47]. Conversely, FGFR4 is expressed in embryonic pancreatic rudiments, characterized by high proliferation of precursors [35]. FGFR3 down-regulation by obestatin at day 2 may be linked to increased proliferation/decreased apoptosis of MLCs. Moreover, obestatin-induced FGFR4 down-regulation may relate to reduced proliferation (day 2) and improved differentiation (day 2 and 9) of committed cells.

FGFR stimulates Notch signaling, which inhibits Ngn3 expression, preventing untimely endocrine differentiation of pancreatic progenitors and allowing their expansion during pancreas development [38]. In obestatin-treated cultures, Notch 2 and 4 down-regulation at day 2 and 6 may follow reduced FGFRs signaling at day 2. Obestatin-induced up-regulation of Notchl at day 9 may be part of a feedback mechanism in response to Ngn3 up-regulation $[32,38]$ across stage 5 , and may be opposed by the Notch1 functional antagonist Notch3 [38].

Ngn3, transiently expressed in committed precursors, is essential to their endocrine differentiation $[3,28]$ and involved in islet formation [48] and $\beta$-cell regeneration [33,42]. Obestatin increased Ngn3 gene expression in MLCs at day 9 and reduced their proliferation, suggesting commitment toward the endocrine fate [31].

Interestingly, glucagon ${ }^{+}$cells influence islet formation and fission during the second wave of Ngn3 up-regulation during pancreas ontogeny [49]. Obestatin induced glucagon expression at day 9. Simultaneously, ICG number was increased and ICG size decreased under obestatin treatment. Regardless of the shorter time, the above events recall those of islet fission, whereby an increase of glucagon ${ }^{+}$cells at the sites of fission was noticed, followed by a transient reduction in islet size and increase in their number [49]. Therefore, obestatin-induced formation of equalsized, more abundant and more differentiated ICGs compared to control, through increase in their number, initial size reduction and subsequent return to control size, is reminiscent of islet fission.

As glucagon ${ }^{+}$cell proliferation is also involved in $\beta$-cell/ pancreas regeneration [39], the above mechanisms may also participate to obestatin-induced pancreas regeneration [25,39] and suggest a possible role in the endocrine pancreas maturation [50].

In summary, obestatin enhances in vitro generation of functional ICGs from islet-derived MLCs, and increases glucose-dependent C-peptide secretion. Whether these findings would be reproducible in human pancreatic islets, they may suggest implications in cell replacement therapy and highlight obestatin importance as therapeutic candidate in diabetes treatment. Moreover, obestatin modulation of FGFR/Notch/Ngn3 developmental pathways, combined to evidence of its early expression in the developing pancreas [50], suggests a role for this peptide in pancreas regeneration and formation.

\section{Supporting Information}

Figure S1 GPR39 and GLP-1R expression in control and obestatin-treated cultures. (A) GPR39 and GLP-1R gene expression assessed by RT-PCR in enriched islets and in cultures at day 6 of stage 4 . Results are representative of three independent experiments. Buffer alone was used as negative control (-). (B) Immunofluorescent staining of GPR39 and GLP-1R in MLCs in control and obestatin-treated cultures at the end of stage 4 . Receptors are shown in green and nuclei in blue (DAPI). Each image is representative of three independent experiments (X40). (EPS)

Figure S2 Glucose-induced insulin secretion by ICGs, and insulin levels in cell culture medium. (A) Insulin secretion assessed by RIA in ICCs stimulated with the indicated concentrations of glucose. Values are the mean \pm SEM of three independent experiments $(* P<0.05, \quad * * P<0.01$ vs. control; ${ }^{\# \#} P<0.01$ same condition vs. $0 \mathrm{mM}$ glucose). (B) Insulin content measured in $300 \mu \mathrm{l}$ of growth medium from control and obestatintreated cultures, at the indicated time points. Insulin content was also assessed in the medium before being added to the cultures (Medium stage 4 and 5). Results are the mean \pm SEM of three independent experiments ( $P<0.05$ vs. day 9 ; ${ }^{\# \#} P<0.01$ vs. day $6, \mathrm{n}=3)$.

(EPS)

Figure S3 Obestatin inhibits FGF2 binding to MLGs at stage 5. FGF+MLCs were cultured in FGF-starved conditions, in either absence or presence of obestatin at the indicated days. Graph shows the results expressed as percent of total cell number, that are the mean \pm SEM of three independent experiments performed in duplicate $(* \mathrm{P}<0.05$ vs. 
control). Right panel. Representative images (X20) of FGF2 staining (green) $(\mathrm{n}=3)$; nuclei are shown in blue (DAPI).

(EPS)

Table S1 Primers sequences, expected length of amplification products and PGR conditions (bp, base pair; mT, melting temperature).

(EPS)

Table S2 Enumeration of endocrine hormone-producing cells and BrdU+ cells (stage 5 , day 9 ).

(EPS)

\section{References}

1. Aguayo-Mazzucato C, Bonner-Weir S (2010) Stem cell therapy for type 1 diabetes mellitus. Nat Rev Endocrinol 6: 139-148.

2. Alipio Z, Liao W, Roemer EJ, Waner M, Fink LM, et al. (2010) Reversal of hyperglycemia in diabetic mouse models using induced-pluripotent stem (iPS)derived pancreatic beta-like cells. Proc Natl Acad Sci U S A 107: 13426-13431.

3. D'Amour KA, Bang AG, Eliazer S, Kelly OG, Agulnick AD, et al. (2006) Production of pancreatic hormone-expressing endocrine cells from human embryonic stem cells. Nat Biotechnol 24: 1392-1401.

4. Chandra V, Swetha G, Muthyala S, Jaiswal AK, Bellare JR, et al. (2011) Isletlike cell aggregates generated from human adipose tissue derived stem cells ameliorate experimental diabetes in mice. PLoS One 6: e20615.

5. Li HY, Chen YJ, Chen SJ, Kao CL, Tseng LM, et al. (2010) Induction of insulin-producing cells derived from endometrial mesenchymal stem-like cells. J Pharmacol Exp Ther 335: 817-829.

6. Kordowich S, Mansouri A, Collombat P (2010) Reprogramming into pancreatic endocrine cells based on developmental cues. Mol Cell Endocrinol 323: 62-69.

7. Kodama S, Toyonaga T, Kondo T, Matsumoto K, Tsuruzoe K, et al. (2005) Enhanced expression of PDX-1 and Ngn3 by exendin-4 during beta cell regeneration in STZ-treated mice. Biochem Biophys Res Commun 327: 11701178.

8. Solar M, Cardalda C, Houbracken I, Martin M, Maestro MA, et al. (2009) Pancreatic exocrine duct cells give rise to insulin-producing beta cells during embryogenesis but not after birth. Dev Cell 17: 849-860.

9. Bonner-Weir S, Li WC, Ouziel-Yahalom L, Guo L, Weir GC, et al. (2010) Betacell growth and regeneration: replication is only part of the story. Diabetes 59: 2340-2348.

10. Liu H, Guz Y, Kedees MH, Winkler J, Teitelman G (2010) Precursor cells in mouse islets generate new beta-cells in vivo during aging and after islet injury. Endocrinology 151: 520-528.

11. Choi Y, Ta M, Atouf F, Lumelsky N (2004) Adult pancreas generates multipotent stem cells and pancreatic and nonpancreatic progeny. Stem Cells 22: $1070-1084$.

12. Davani B, Ikonomou L, Raaka BM, Geras-Raaka E, Morton RA, et al. (2007) Human islet-derived precursor cells are mesenchymal stromal cells that differentiate and mature to hormone-expressing cells in vivo. Stem Cells 25: 3215-3222.

13. Gershengorn MC, Hardikar AA, Wei C, Geras-Raaka E, Marcus-Samuels B, et al. (2004) Epithelial-to-mesenchymal transition generates proliferative human islet precursor cells. Science 306: 2261-2264

14. Morton RA, Geras-Raaka E, Wilson LM, Raaka BM, Gershengorn MC (2007) Endocrine precursor cells from mouse islets are not generated by epithelial-tomesenchymal transition of mature beta cells. Mol Cell Endocrinol 270: 87-93.

15. Ta M, Choi Y, Atouf F, Park CH, Lumelsky N (2006) The defined combination of growth factors controls generation of long-term-replicating islet progenitorlike cells from cultures of adult mouse pancreas. Stem Cells 24: 1738-1749.

16. Mutskov V, Raaka BM, Felsenfeld G, Gershengorn MC (2007) The human insulin gene displays transcriptionally active epigenetic marks in islet-derived mesenchymal precursor cells in the absence of insulin expression. Stem Cells 25: 3223-3233.

17. Ouziel-Yahalom L, Zalzman M, Anker-Kitai L, Knoller S, Bar Y, et al. (2006) Expansion and redifferentiation of adult human pancreatic islet cells. Biochem Biophys Res Commun 341: 291-298.

18. Zhang JV, Ren PG, Avsian-Kretchmer O, Luo CW, Rauch R, et al. (2005) Obestatin, a peptide encoded by the ghrelin gene, opposes ghrelin's effects on food intake. Science 310: 996-999.

19. Chartrel N, Alvear-Perez R, Leprince J, Iturrioz X, Reaux-Le Goazigo A, et al. (2007) Comment on "Obestatin, a peptide encoded by the ghrelin gene, opposes ghrelin's effects on food intake". Science 315: 766; author reply 766.

20. Granata R, Baragli A, Settanni F, Scarlatti F, Ghigo E (2010) Unraveling the role of the ghrelin gene peptides in the endocrine pancreas. J Mol Endocrinol 45: $107-118$.

21. Granata R, Settanni F, Gallo D, Trovato L, Biancone L, et al. (2008) Obestatin promotes survival of pancreatic beta-cells and human islets and induces expression of genes involved in the regulation of beta-cell mass and function. Diabetes 57: 967-979.

\section{Acknowledgments}

We thank Fiorella Altruda, Marta Annunziata, Giovanni Camussi, Gabriele Togliatto and Letizia Trovato (all from the University of Torino, Italy) for their contribution to the study.

\section{Author Contributions}

Conceived and designed the experiments: A.B R.G. Performed the experiments: A.B. G.G. I.G. FS. M.T. D.G. El.Garg. Analyzed the data: A.B. R.G. Contributed reagents/materials/analysis tools: A.B. G.G. I.G. FS. M.T. D.G. El.Garg. Wrote the paper: A.B. Ez.Gh. R.G.

22. Granata R, Gallo D, Luque RM, Baragli A, Scarlatti F, et al. (2012) Obestatin regulates adipocyte function and protects against diet-induced insulin resistance and inflammation. FASEB J 26: 3393-3411.

23. Egido EM, Hernandez R, Marco J, Silvestre RA (2009) Effect of obestatin on insulin, glucagon and somatostatin secretion in the perfused rat pancreas. Regul Pept 152: 61-66.

24. Granata R, Settanni F, Biancone L, Trovato L, Nano R, et al. (2007) Acylated and unacylated ghrelin promote proliferation and inhibit apoptosis of pancreatic beta-cells and human islets: involvement of 3',5'-cyclic adenosine monophosphate/protein kinase A, extracellular signal-regulated kinase 1/2, and phosphatidyl inositol 3-Kinase/Akt signaling. Endocrinology 148: 512-529.

25. Granata R, Volante M, Settanni F, Gauna C, Ghe C, et al. (2010) Unacylated ghrelin and obestatin increase islet cell mass and prevent diabetes in streptozotocin-treated newborn rats. J Mol Endocrinol 45: 9-17.

26. Chanoine JP, Wong AC, Barrios V (2006) Obestatin, acylated and total ghrelin concentrations in the perinatal rat pancreas. Horm Res 66: 81-88.

27. Shewade YM, Umrani M, Bhonde RR (1999) Large-scale isolation of islets by tissue culture of adult mouse pancreas. Transplant Proc 31: 1721-1723.

28. Rukstalis JM, Habener JF (2009) Neurogenin3: a master regulator of pancreatic islet differentiation and regeneration. Islets 1: 177-184.

29. Hansson M, Tonning A, Frandsen U, Petri A, Rajagopal J, et al. (2004) Artifactual insulin release from differentiated embryonic stem cells. Diabetes 53: 2603-2609

30. Rubenstein AH, Block MB, Starr J, Melani F, Steiner DF (1972) Proinsulin and C-peptide in blood. Diabetes 21: 661-672.

31. Miyatsuka T, Kosaka Y, Kim H, German MS (2011) Neurogenin3 inhibits proliferation in endocrine progenitors by inducing Cdknla. Proc Natl Acad Sci U S A 108: 185-190.

32. Treff NR, Vincent RK, Budde ML, Browning VL, Magliocca JF, et al. (2006) Differentiation of embryonic stem cells conditionally expressing neurogenin 3 . Stem Cells 24: 2529-2537.

33. Wang S, Jensen JN, Seymour PA, Hsu W, Dor Y, et al. (2009) Sustained Neurog3 expression in hormone-expressing islet cells is required for endocrine maturation and function. Proc Natl Acad Sci U S A 106: 9715-9720.

34. Russ HA, Bar Y, Ravassard P, Efrat S (2008) In vitro proliferation of cells derived from adult human beta-cells revealed by cell-lineage tracing. Diabetes 57: 1575-1583.

35. Le Bras S, Miralles F, Basmaciogullari A, Czernichow P, Scharfmann R (1998) Fibroblast growth factor 2 promotes pancreatic epithelial cell proliferation via functional fibroblast growth factor receptors during embryonic life. Diabetes 47 : $1236-1242$.

36. Lumelsky N, Blondel O, Laeng P, Velasco I, Ravin R, et al. (2001) Differentiation of embryonic stem cells to insulin-secreting structures similar to pancreatic islets. Science 292: 1389-1394.

37. Hardikar AA, Marcus-Samuels B, Geras-Raaka E, Raaka BM, Gershengorn MC (2003) Human pancreatic precursor cells secrete FGF2 to stimulate clustering into hormone-expressing islet-like cell aggregates. Proc Natl Acad Sci U S A 100: 7117-7122.

38. Kim W, Shin YK, Kim BJ, Egan JM (2010) Notch signaling in pancreatic endocrine cell and diabetes. Biochem Biophys Res Commun 392: 247-251.

39. Thorel F, Nepote V, Avril I, Kohno K, Desgraz R, et al. (2010) Conversion of adult pancreatic alpha-cells to beta-cells after extreme beta-cell loss. Nature 464: 1149-1154.

40. Kroon E, Martinson LA, Kadoya K, Bang AG, Kelly OG, et al. (2008) Pancreatic endoderm derived from human embryonic stem cells generates glucose-responsive insulin-secreting cells in vivo. Nat Biotechnol 26: 443-452.

41. Rankin MM, Kushner JA (2009) Adaptive beta-cell proliferation is severely restricted with advanced age. Diabetes 58: 1365-1372.

42. Xu X, D'Hoker J, Stange G, Bonne S, De Leu N, et al. (2008) Beta cells can be generated from endogenous progenitors in injured adult mouse pancreas. Cell 132: 197-207.

43. Chen W, Begum S, Opare-Addo L, Garyu J, Gibson TF, et al. (2009) Promotion of beta-cell differentiation in pancreatic precursor cells by adult islet cells. Endocrinology 150: 570-579. 
44. Miralles F, Czernichow P, Ozaki K, Itoh N, Scharfmann R (1999) Signaling through fibroblast growth factor receptor $2 \mathrm{~b}$ plays a key role in the development of the exocrine pancreas. Proc Natl Acad Sci U S A 96: 6267-6272.

45. Elghazi L, Cras-Meneur C, Czernichow P, Scharfmann R (2002) Role for FGFR2IIIb-mediated signals in controlling pancreatic endocrine progenitor cell proliferation. Proc Natl Acad Sci U S A 99: 3884-3889.

46. Liu DW, Hsu CH, Tsai SM, Hsiao CD, Wang WP (2011) A variant of fibroblast growth factor receptor 2 (Fgfr2) regulates left-right asymmetry in zebrafish. PLoS One 6: e21793.
47. Arnaud-Dabernat S, Kritzik M, Kayali AG, Zhang YQ, Liu G, et al. (2007) FGFR3 is a negative regulator of the expansion of pancreatic epithelial cells. Diabetes 56: 96-106.

48. Gouzi M, Kim YH, Katsumoto K, Johansson K, Grapin-Botton A (2011) Neurogenin3 initiates stepwise delamination of differentiating endocrine cells during pancreas development. Dev Dyn 240: 589-604.

49. Miller K, Kim A, Kilimnik G, Jo J, Moka U, et al. (2009) Islet formation during the neonatal development in mice. PLoS One 4: e7739.

50. Wierup N, Svensson H, Mulder H, Sundler F (2002) The ghrelin cell: a novel developmentally regulated islet cell in the human pancreas. Regul Pept 107: 6369. 